\title{
Pelatihan Penggunaan dan Pemanfaatan Google Drive Bagi Guru dan Siswa Yayasan Pondok Pesantren Azzainiyah AL-Majidiyah Madrasah Aliyah NW Kota Raja Kec. Sikur Lombok Timur
}

\author{
Intan Kusuma Wardani, Nofisulastri, Siti Rabiatul Adawiah, Fitri Astutik, Arif Yanuar Musrifin \\ Fakultas Ilmu Keolahragaan dan Kesehatan Masyarakat \\ Universitas Pendidikan Mandalika Mataram \\ intankusumawardani@ikipmataram.com
}

\begin{abstract}
Abstrak; Pesatnya kemajuan Teknologi Informasi dan layanan internet di Indonesia dan khususnya pelayanan internet mobile menjadikan handphone atau tablet pc menjadi semakin powerfull. Sedangkan mobilitas pemakai internet sudah tidak dibatasi lagi oleh ruang dan waktu. Mengingat mobilitas yang tinggi tersebut tentunya mengandung resiko akan kehilangan data yang penting yang tersimpan pada perangkat yang digunakan seperti handphone ataupun tablet tersebut, karena itu diperlukan tempat penyimpanan yang cukup "aman", sehingga kalaupun perangkat tersebut hilang atau ketinggalan, kita masih bisa mendapatkan file-file tersebut karena tersimpan secara online di internet. Media penyimpanan yang ada di internet tersebut biasa disebut dengan penyimpanan Cloud yang saat ini banyak didominasi oleh Dropbox, Box, SkyDrive dan GoogleDrive yang akan kita bahasnanti.
\end{abstract}

Kata kunci : google Drive, Drive, Cloud.

\section{PENDAHULUAN}

Menurut sebuah makalah tahun 2008 yang dipublikasikan IEEE Internet Computing : Cloud Computing adalah suatu paradigma di mana informasi secara permanen tersimpan di server-internet dan tersimpan secara sementara di komputer pemakai (client) termasuk di dalamnya adalah computer desktop, komputer tablet, notebook, handheld, dan lain-lain"

cloud computing adalah gabungan pemanfaatan teknologi komputer dan pengembangan berbasisInternet.

cloud adalah metafora dari internet,
sebagaimana digambarkan di diagram jaringankomputer. Sebagaimana awan dalam diagram jaringan komputer tersebut, cloud dalam Cloud Computing juga merupakan abstraksi dari infrastruktur kompleks yang disembunyikannya. Ia adalah suatu metoda komputasi di mana kapabilitas ter-kait teknologi informasi disajikan sebagai suatu layanan sehingga pengguna dapat mengaksesnya lewat Internet.

Abdi Masyarakat

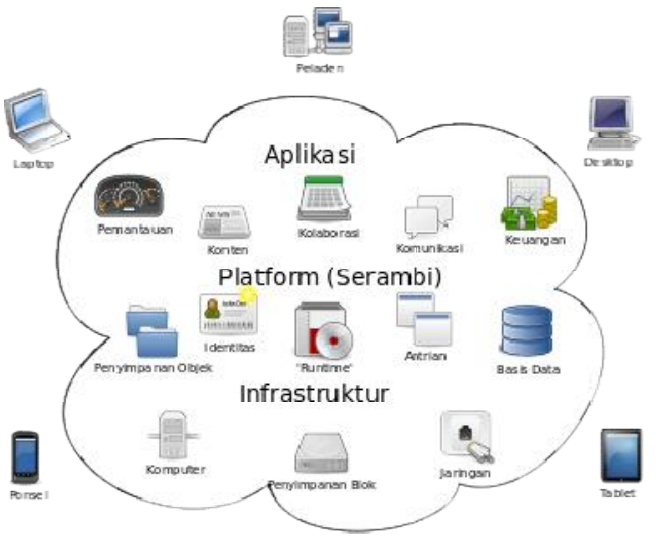

Gambar : 1 Cloud Computing

Google sebagai perusahaan yang sangat berpengaruh di layanan internet tentunya tidak akan tinggal diam saja melihat perkembangan yang ada dan tentunya ikut ambil bagian dalam pertarungan pelayanan tersebut. Untuk itu Google meluncurkan Google Drive, layanan penyimpanan online yang saat ini didominasi oleh Dropbox, Box dan SkyDrive.

Layanan gratis „freemium ${ }^{\text {ee Google }}$ Drive ini menggantikan fungsi Google Docs dan memudahkan kita untuk menyimpan file 
serta mengaksesnya di berbagai perangkat digital termasuk komputer, handphone dan tablet dimanapun kita berada.

Untuk dapat menikmati layanan Google- Drive dengan cara bergabung denganlayanan Google yang cukup mudah. Hanya dengan mengunjungi situs drive.google.com dan mengaktifkan layanan tersebut. Setelah kita mendapatkan akses di Google Drive, dengan segera kita dapat menggunakannya. Sebenarnya layanan ini mirip dengan Google Docs, kita dapat membuat file, folder, untuk melakukan pencarian dan meng-upload file. Bedanya adalah, di aplikasi Google Drive, kita dapat mengatur seluruh drive dari desktopkomputer.

\section{Menggunakan Google Drive}

\section{Langkah-langkah mengaktifkan Google} Drive:

a. Kunjungi situswww.google.com

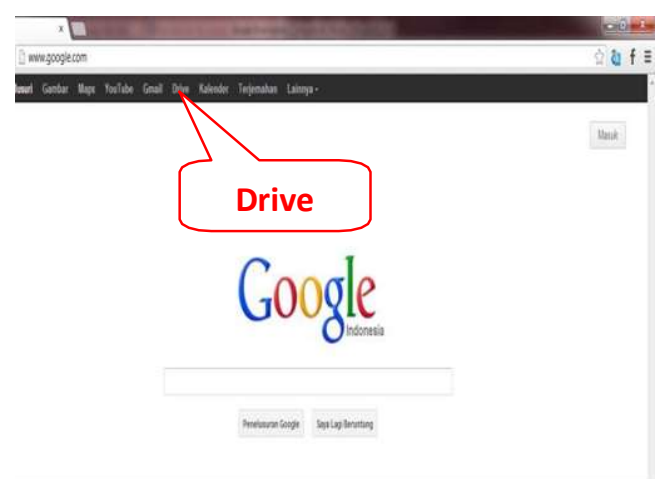

b. Pilih "Drive" yang ada di sidebar atas, maka kita langsung menuju ke drive.google.com. Kalau kita baru menggunakan fasilitas ini, maka diperlukan mendaftar terlebih dahulu dengan tekan/klik menu Sign-Up (Daftar), dan isi form yang disediakan, yang diperlukan disini adalah alamat email kitasaja.
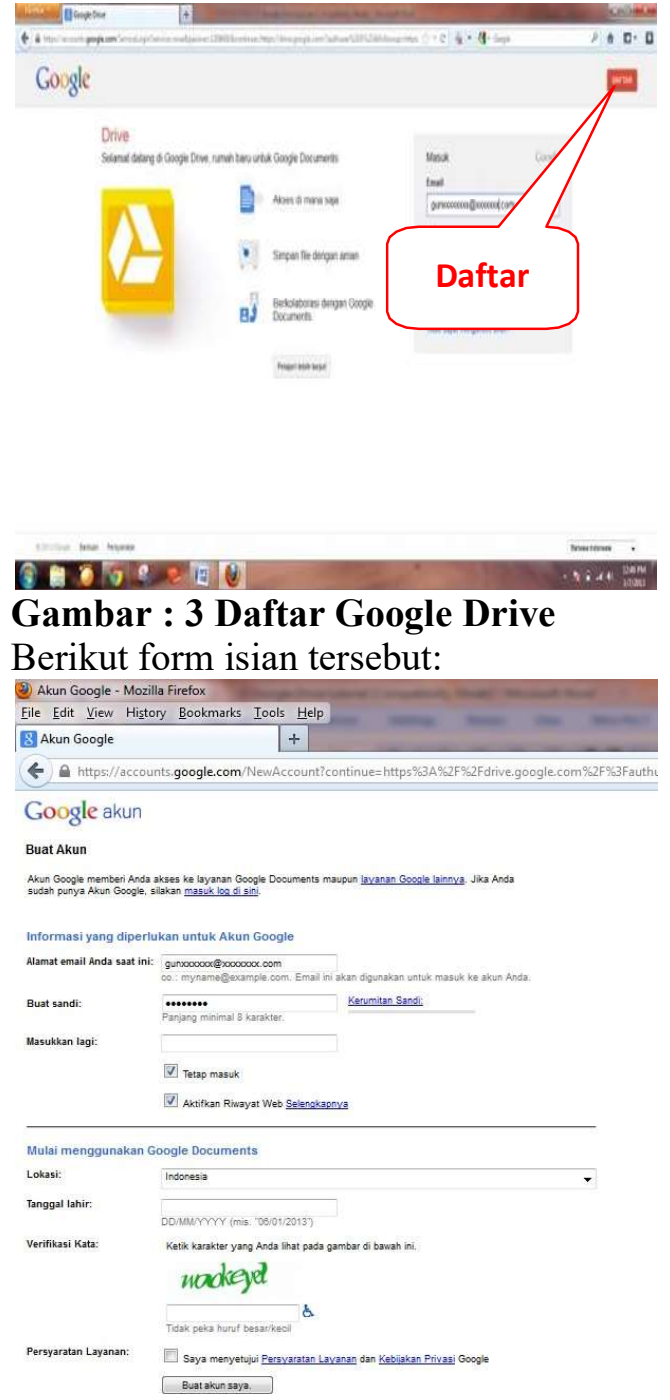

Gambar : 4 Form GoogleDrive

Setelah selesai mendaftar, sekarang kita lansung masuk / Check-In.

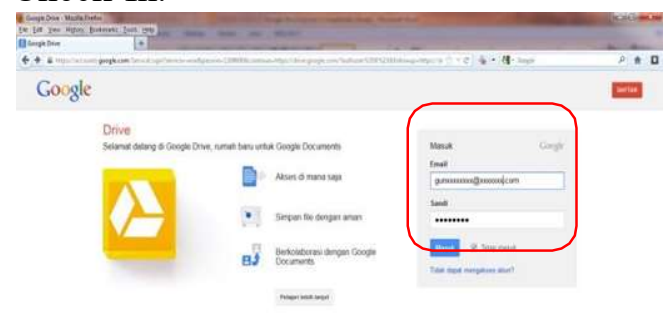

Gambar : 5 Masuk ke Google Drive

Bila sudah selesai, maka sekarang kita sudah memiliki media penyimpan di internet 
dengan kapasitas 5 GB.

c. File-file yang kita simpan di Google Drive adalah file-file penting yang bisa jadi sewaktu-waktu kita butuhkan, sementara kita tidak selalu membawa laptop, flashdisk atau media penyimpan yang lainnya, untuk itulah Google Drive ini berperan penting, sepanjang ada sambungan ke internet, maka file-file tersebut dapat kita akses.

d. Google Drive ini dapat kita akses dan edit, rubah dan buka dengan perangkat laptop yang kita miliki maupun dengan handset kita yang bersistem operasi Android, dengan demikian setidaknya kita memiliki backup di beberapa tempat. File-file tersebut akan secara otomatis ter- update apabila pada salah satu tempatdilakukan perubahan. Untuk itu diperlukan penginstalan program pada PC maupun Handset Android dengan men-download pada "PlayStore".
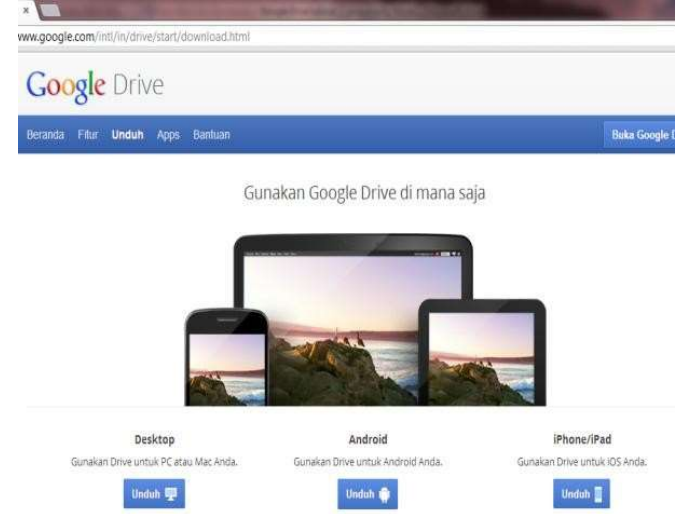

Gambar : 6 Lintas Perangkat Google Drive

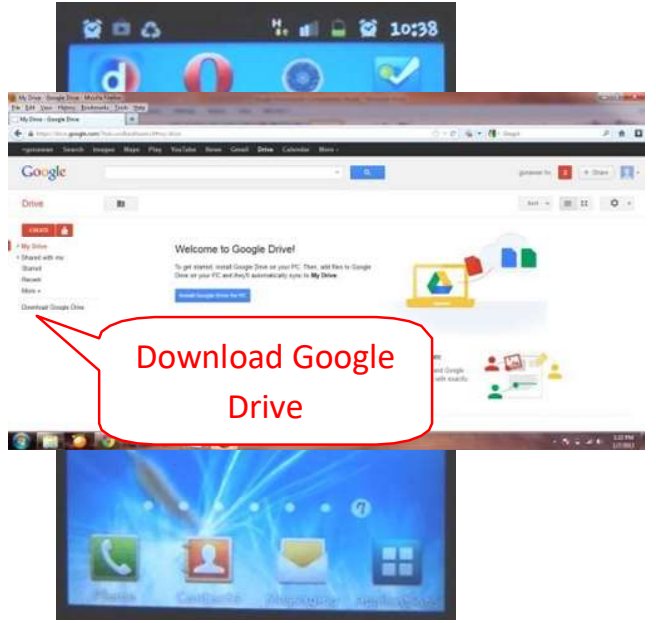

Gambar : 7 Google Drive di Handset e. Setelah proses download dan instalasi selesai, maka akan tampil folder "Google Drive" di desktop kita, dimana folder ini bisa kita tentukan pada drive yang mana, saran saya jangan diletakkan di drive C:, sehingga bilamana terjadi sesuatu yang tidak diinginkan dengan windows kita, maka folder tersebut tidak hilang.

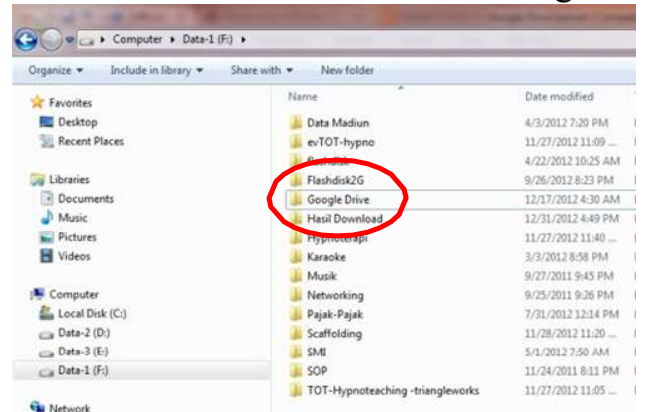

Gambar : 8 Folder Google Drive di PC

f. Folder tersebut tersinkronisasi dengan layanan Google Drive, sehingga setiap perubahan yang Anda lakukan akan direfleksikan di interface Web, begitu juga sebaliknya. Dengan demikian, ketika Anda menambahkan file ke folder Google Drive, secara langsung akan ter-upload ke drive Web Anda (selama koneksi internet diaktifkan).

\section{Fitur yangtersedia}

a. Kapasitas penyimpanan dokumen hingga 5 Giga Byte.

Google Drive akan memberikan ruang penyimpanan gratis bagi penggunanya sebesar 5GB, tidak terhitung dokumen yang kita buat melalui Drive. Kita dapat mengupload 30 jenis file termasuk file Photoshop, video, foto dan sebagainya. Google Drive mendukung hampir seluruh jenis file yang populer.

b. Berbagi file, folder dan seluruh isi drive kita.

Sama seperti Google Docs, kita dapat berbagi file melalui Google Drive. Hanya dengan meng-klik kanan di file atau folder dan memilih "Share" dan memilih opsi sharing yang ada. Untuk mengijinkan seseorang dapat mengakses seluruh drive Anda, klik tombol orang tersebut dan tanda tambah (plus) di bagianatas.

c. Menggunakan sistem pencari Google. 
Dengan teknologi pencarian Google yang dibenamkan di aplikasi Google Drive, Anda dapat melakukan pencarian foto pada bagian, ,search ${ }^{\text {ee }}$. Anda juga dapat melakukan pencarian teks pada dokumen yang di-scan. Setelah beberapa pengujian, fitur ini ternyata tidak sepenuhnya dapat dipercaya, tapi cukup pantas untuk dicoba sebagai penolong pencarian file ataufoto.

d. Mengkolaborasikan video, foto dan lainnya.Fitur kolaborasi Google Docs sekarang tersedia untuk berbagai jenis file. Sebagai contoh, jika Anda mengupload sebuah video di Drive dan berbagi dengan seseorang, Anda dapat berdiskusi mengenai video tersebut dengan fasilitas komentar.

e. Menginstal aplikasi dari pihak ketiga. Developer pihak ketiga dapat membangun aplikasi yang dapat bekerja dengan baik di Google Drive. Anda dapat melakukan edit foto dengan menggunakan aplikasi Pixlr, mengirim fax secara gratis dengan aplikasi HelloFax dan menandatangani dokumen resmi dengan aplikasi DocuSign. Semuanya dapat dilakukan lewat layanan Google Drive. Untuk mendapatkan aplikasi ini dan lainnya, kunjungi Google Drive $>$ Settings $>$ Manage apps $>$ Get moreapps.

\section{Keunggulan :}

a. Goole Drive menyediakan ruang penyimpanan sebesar 5 Giga Byte secara gratis.

b. Google Drive terintegrasi dengan layanan Google lainnya.

Hampir seluruh aplikasi dari Google terintegrasi dengan baik di Google Drive. Seperti untuk melakukan lampiran file (attachment) di Gmail, kita dapat mengakses file dengan cepat melalui Google Drive dan pengguna Google+ dapat memudahkan kita dalam mencarivideo dan gambar di penyimpanan Drivesecara instan untuk mensharingnya di jejaring sosial.

c. Google Drive tidak membatasi Aplikasi dari pihak ketiga, bahkan membuka peluang bagi pihak ketiga untuk membuat aplikasi yang dapat didukung oleh Google Drive.

d. Pihak pengembang Sistem Operasi seperti : Window, Mac dan Android turut serta meramaikan Google Drive. Salah satu keunggulan penting Google Drive adalah layanan ini dapat mendukung berbagai platform termasuk Mac/Apple dan Microsoft.

e. Google Drive dapat mendukung berbagai jenis file. Dalam aplikasi Google Drive dimungkinkan dengan pendukung file native yang dapat mendukung hingga 30 jenis aplikasi format file berbeda. Jadi kita tetap dapat membuka file seperti Photoshop atau Illustrator meskipun tidak memiliki aplikasi tersebut di komputernya.

f. Menurut Google, Google Drive mengijinkan pengguna untuk mengecek perubahan yang mereka lakukan dalam batas 30 hari sebelumnya. Lebih lanjut, Google Drive juga menyediakan cara lain bagi Anda untuk dapat menyimpan langkah revisispesifik.

g. Google Drive juga menyediakan layanan berbayar yang dapat memperbesar ruang penyimpanan.

h. Teknologipencarian.

Seperti sejarah Google sebagai mesin pencari terbesar di dunia, pastinyaperusahaan akan mengaplikasikan teknologi pencarian juga di Drive. Google Drive mengatakan bahwa pengguna dapat melakukan pencarian berdasarkan kata kunci, jenis file, pemilik dan atribut lainnya. Bahkan juga dapat mencari dengan teknologi penyenalan gambar dan obyek yang berada di hasil scan suatudokumen.

\section{KESIMPULAN}

1. Google Drive merupakan media penyimpan yang bisa dihandalkan, sehingga kita tidak akan kesulitan apabila data-data penting kita tertinggal atau hilang, kita masih bisa menggunkanan data/file tersebut dengan mengambilnya di aplikasi Google Drive, persyaratannya hanyalah ada sambungan internet.

2. Google Drive sebagai media penyimpan 
di cloud yang disokong oleh Google, dimana sekarang ini Google merupakan perusahaan yang sangat besar bahkan bisa dikatakan sebagai perusahaan nomor satu dalam pelayanan internet. Terlebih aplikasi ini akan dibuat untuk bisa dipakai pada lintas platform system operasi yang banyak digunakan sekarang ini, seperti pada windows, Machintos, kemudian pada system operasi yang dipakai di handset seperti : Android, dan IOs. Sehingga dengan dapat dipergunakan pada bermacam-macam platform system operasi baik itu untuk laptop maupun handset, maka kita sudah tidak perlu kawatir lagi apabila kita berganti system operasi maka tidak akan bisa lagi menggunakan aplikasiini.

DAFTAR PUSTAKA

http://id.wikipedia.org/wiki/Komputasi_awan

https://support.google.com

http://www.rikhojansen.com

/tips-how-to/3263-fitur-

keunggulan-dan-tutorial-

cara- menggunakan-google-

drive.htm 